\title{
PENGARUH MANAJEMEN KEPENGURUSAN PESANTREN TERHADAP BUDAYA MEMBACA AL- QUR'AN DI PONDOK PESANTREN NURUL HUDA PRINGSEWU
}

\author{
Oleh: \\ Nur 'Aida Fitriani, Dwi Rohmadi Mustofa, Muhtarom \\ Nuraida@gmail.com, dwirohmadimustofa91@gmail.com, muhtarom@gmail.com
}

\begin{abstract}
This study aims to determine the effect of boarding school management on al-Qur'an reading culture at nurul huda pringsewu boarding school. This research is a quantitative study by taking samples of 24 female students of second grade B madrasah diniyah nurul huda.

Data collection methods in this study are using the method of observation, questionnaires and documentation. In this study, two variables are used, namely management of pesantren management as the dependent variable $(\mathrm{X})$ and the culture of reading al-Qur'an free variables (Y). Analysis of research instruments includes validity and reliability tests. Analysis of the data used is linear analysis.

The results of this study indicate that the management of boarding schools in Islamic boarding schools Nurul Huda Pringsewu are in the strong category with a value of. 716 and the culture of reading the Qur'an is in the strong category with tilapia. 747. the results of linear analysis, management of boarding school management to the culture of reading the Koran shows that the significance coefficient value is 0.787 with an alpha value of 0.05. This means that there is a significant influence between the management of the boarding school management on the culture of reading the Qur'an at the boarding school nurul huda pringsewu in the 2016/2017 school year. So, it can be concluded that the management of boarding schools is very influential on the culture of reading the Qur'an.
\end{abstract}

Keywords: boarding school management, al-reading culture The Qur'an

\begin{abstract}
ABSTRAK
Penelitian ini bertujuan untuk mengetahui pengaruh manajemen kepengurusan pesantren terhadap budaya membaca al-Qur'an di pondok pesantren nurul huda pringsewu. Penelitian ini merupakan penelitian kuantitatif dengan mengambil sample 24 santri putri kelas dua B madrasah diniyah nurul huda.

Metode pengumpulan data dalam penelitian ini adalah menggunakan metode observasi, angket dan dokumentasi. Dalam penelitian ini digunakan dua variabel yaitu manajemen kepengurusan pesantren sebagai variable terikat $(\mathrm{X})$ dan budaya membaca al-Qur'an variable bebas $(\mathrm{Y})$. Analisis instrument penelitian meliputi uji validitas dan reabilitas. Analisis data yang digunakan adalah analisis linier.

Hasil penelitian ini menunjukkan bahwa manajemen kepengurusan pesantren di pondok pesantren nurul huda pringsewu berada pada katagori kuat dengan nilai .716 dan budaya membaca al-Qur'an berada pada katagori kuat dengan nila .747. hasil analisis linier, manajemen kepengurusan pesantren terhadap budaya membaca al-Qur'an menunjukkan bahwa nilai koefisien signifikasi 0,787 dengan nilai alpha 0,05. Hal ini berarti ada pengaruh yang signifikan antara manajemen kepengurusan pesantren terhadap budaya membaca al-Qur'an di pondok pesantren nurul huda pringsewu tahun ajaran 2016/2017.

Jadi, dapat disimpulkan bahwa manjemen kepengurusan pesantren sangat berpengaruh terhadap budaya membaca al-Qur'an.
\end{abstract}

Kata kunci: manajemen kepengurusan pesantren, budaya membaca al-Qur'an 


\section{A. Latar Belakang}

Menurut UU RI Nomor 20 tahun 2003, "Pengertian Pendidikan adalah usaha sadar dan terencana untuk mewujudkan suasana belajar dan proses pembelajaran agar peserta didik secara aktif mengembangkan potensi dirinya untuk memiliki kekuatan spiritual keagamaan, pengendalian diri, kepribadian, kecerdasan, akhlak mulia, serta keterampilan yang diperlukan dirinya, masyarakat, bangsa dan negara (Nur Aedi, 2015: 30).

Sejalan dengan itu didalam UndangUndang Republik Indonesia Nomor 20 Tahun 2003 tentang Sistem PendidikanNasional dan UU Nomor 14 Tahun 2005 tentang Guru dan Dosen, pasal 3 menyatakan bahwa "Pendidikan Nasional bertujuan untuk berkembangnya potensi peserta didik agar menjadi manusia yang beriman dan bertaqwa kepada Tuhan Yang Maha Esa, berakhlak mulia, sehat, berilmu, cakap, kreatif, mandiri, dan menjadi warga negara yang demokratis serta bertanggung jawab." Dengan terwujudnya pendidikan nasional tercipta generasi masa depan yang berkepribadian baik.

Didalam mewujudkan pendidikan nasionalmenemui permasalahan yang komplek dan rumit. Akan tetapi yang paling penting adalah manajemennya. Keberhasilan manajemen akan menjadi barometer keberhasilan pendidikan itu sendiri.

Menurut Pidarta, Manajemen pendidikan ialah proses perencanaan, pengorganisasian, memimpin, mengendalikan tenaga pendidikan, sumber daya pendidikan untuk mencapai tujuan pendidikan, mencerdaskan kehidupan bangsa, mengembangkan manusia seutuhnya, yaitu manusia yang beriman, bertakwa kepada Tuhan Yang Maha Esa, berbudi pekerti yang luhur, memiliki pengetahuan, keterampilan, kesehatan jasmani dan rohani, kepribadian yang mantap, mandiri, serta bertanggung jawab ke masyarakat dan kebangsaan (Rustam Ibrahim, 2014: 29)

Manajemen pendidikan juga mengarahkan siswanya untuk memiliki iman dan taqwa serta menanamkan kecintaan kepada Alloh dan Nabi Muhammad SAW dengan mengikuti semua ucapan, perbuatan dan suri tauladan-Nya sesuai pada QS. 'Ali Imron 31-32 sebagai berikut :

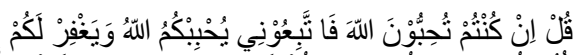

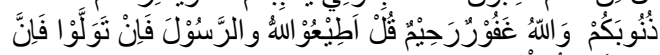
اللَّهَ لاَيَحِبُُ الْكَفِرِيْنَ

Katakanlah: "Jika kamu (benar-benar) mencintai Alloh, ikutilah aku, niscaya Alloh mengasihi dan mengapuni dosa-dosamu." Alloh Maha pengampun lagi Maha penyayang. Katakanlah:"Taatilah Alloh dan Rasul-Nya: jika kamu, maka sesungguhnya Alloh tidak menyukai orang-orang yang kafir. (QS. 'Ali Imron 31-32) (Departemen Agama RI, Alqur'an dan Terjemahnya. 1992)

Nabi Muhammad SAW bersabda (dalam Utsman Bin Hasan Bin Ahmad As-Syakur Al Khawabiri, hal 54)

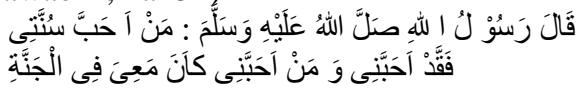

"Barang siapa mencintaiku, maka benar-benar mencintaiku. Dan barang siapa yang mencintaiku, maka dia akan bersama ku di syurga." (HR. Anas Rodiyallohu'Anhu).

Ayat dan hadits ini menerangkan bahwa kita semua di anjurkan untuk mencintai Nabi Muhammad SAW seperti halnya beliau mencintai Allah SWT dengan mengikuti dan mengamalkan segala perkataan dan perbuatannya (sunnah-sunnahnya).

Berkaitan dengan ayat dan hadits diatas peneliti akan menitik fokuskan pada hal menghafal hadits pada siswa jenjang pendidikan Raudhatul Athfal (RA), karena pada jenjang ini anak dianggap harus mempunyai kesiapan untuk menempuh jenjang pendidikan selanjutnya.

Menurut Direktorat Pembinaan Pendidikan Anak Usia Dini (2012:2) tentang pengertian Pendidikan anak usia dini adalah suatu upaya pembinaan yang ditujukan kepada anak sejak lahir sampai dengan usia enam tahun yang dilakukan melalui pemberian rangsangan pendidikan untuk membantu pertumbuhan dan perkembangan jasmani dan rohani agar anak memiliki kesiapan dalam memasuki pendidikan lebih lanjut.

Pendidikan jasmani dan rohani kepada anak-anak usia dini dapat diwujudkan dengan menanamkan kecintaan kepada Nabi Muhammad SAW melalui menghafal haditshadits sederhana. Jika hadits sudah di kenalkan, di hafal dan di terapkan dalam kehidupan sehari-hari, maka anak lebih mudah untuk di bentuk dan di arahkan ke prilaku yang akhlakul karimah hingga dewasa kelak.

Pada penelitian ini penulis mengadakan observasi di RA Roudhotul Ishlah Margosari yang terletak di Jalan Pasar Kayu Desa Margosari Kecamatan Pagelaran Utara Kabupaten Pringsewu.

RA Roudhotul Ishlah merupakan sekolah yang bernuansa islami yang mengutamakan pengembangan nilai moral dan keagamaan dan ditunjang dengan pembelajaran ekstra kurikuler. Didalam pendidikan agama islam, anak 
diberikan pembelajaran yang lebih mendalam tentang mengenal Tuhan Yang Maha Esa yang meliputi tentang asmaul husna, sifat-sifat dan ciptaan-Nya, tata cara beribadah yang meliputi aspek rukun islam yaitu menyebutkan syahadat, menyebutkan jumlah waktu dan rakaat sholat, mengenal ibadah puasa, zakat, sholat (sholat wajib dan sunnah) dan ibadah haji, ibadah qurban, tahfidz qur'an, hafalan do'a harian, hafalan hadits dan lain-lain. Sedangkan dalam kegiatan ekstra kurikuler memberikan pendalaman pada penguasaan membaca iqro' dan kesenian hadroh secara sederhana serta ditambah dengan kegiatan lain yang menunjang pembelajaran.

Didalam pendidikan menghafal hadits, anak lebih menyukai pembelajaran yang menarik, merangsang rasa ingin tahu dan menggunakan banyak gerak tubuh. Selain mendapatkan kesehatan jasmani, dengan gerakan tubuh anak mendapat kesehatan rohani karena anak dapat mengenal dan menghafal hadits yang menjadikannya menjadi anak yang berjiwa religius.

Namun demikian dari hasil observasi awal saat penulis menjalani Program Praktek Lapangan (PPL) diperoleh data bahwa manajemen pendidikan menghafal hadits di RA Roudhotul Ishlah Margosari ditemukan beberapa masalah. Masalah-masalah yang ditemui tersebut diantaranya adalah (1) metode yang digunakan cenderung membosankan, tidak menggunakan kegiatan motorik didalam pembelajarannya, cenderung menuntut anak untuk mendengarkan materi dan menghafalkannya (metode ceramah), (2) tenaga kependidikan yang belum memenuhi standar kompetensi guru, (3) penyediaan sarana prasarana yang kurang memadai, (4) alokasi dan penggunaan pembiayaan yang efektif dan efisien, (5) partisipasi wali murid/ masyarakat yang belum optimal.

Table 1.1 Hasil Pra Survey Manajemen Pendidikan Menghafal Hadits

\begin{tabular}{|c|l|c|c|c|}
\hline \multirow{2}{*}{ No } & \multicolumn{2}{|c|}{ Indikator } & \multicolumn{3}{|c|}{ Hasil } \\
& & Kengamatan \\
\hline & & C & B \\
\hline 1. & Manajemen kesiswaan & & $\checkmark$ & \\
\hline 2 & Manajemen kurikulum & & $\checkmark$ & \\
\hline 3 & $\begin{array}{l}\text { Manajemen tenaga } \\
\text { kependidikan }\end{array}$ & $\checkmark$ & & \\
\hline 4 & $\begin{array}{l}\text { Manajemen sarana } \\
\text { prasarana }\end{array}$ & $\checkmark$ & & \\
\hline 5 & Manajemen keuangan & $\checkmark$ & & \\
\hline 6 & $\begin{array}{l}\text { Manajemen } \\
\text { lingkungan }\end{array}$ & & $\checkmark$ & \\
\hline 7 & Metode pembelajaran & $\checkmark$ & & \\
\hline
\end{tabular}

Sumber : RA Roudhotul Ishlah Margosari
Dari hasil pengamatan pra survey diatas, menunjukkan bahwa didalam komponen manajemen pendidikan di RA Roudhotul Ishlah Margosari belum menunjukkan pengelolaan yang baik dan masih perlu pembenahan di sebagian komponennya. Sedangkan didalam penerapan metode pembelajarannya belum maksimal dan belum disesuaikan dengan tahap perkembangan fisik dan mental pada jenjang pendidikan anak usia dini. Dan dalam hal ini peneliti menerapkan metode yang membuat anak lebih mudah dan menyenangkan secara maksimal yaitu menghafal hadits melalui metode gerakan.

\section{B. Tujuan}

Tujuan dari penelitian yaitu untuk mengetahui tentang manajemen pendidikan menghafal hadits metode menghafal hadits dengan gerakan serta untuk mengetahui faktor pendukung dan penghambat manajemen pendidikan menghafal haditdi RA Roudhotul Ishlah Margosari. Menghafal hadits dengan metode gerakan diharapkan dapat menambah ketertarikan dalam pembelajaran sehingga dapat diperoleh hasil ditentukan.

\section{Metodologi}

Desain penelitian yang digunakan dalam penelitian ini adalah data penelitian kualitatif dengan menggunakan pendekatan kualitatif deskriptif. Subjek dalam penelitian ini adalah seluruh siswa RA Roudhotul Ishlah, sedangkan kepala sekolah dan guru sebagai pendukung kelengkapan informasi. Data yang akan digali meliputi manajemen pendidikan secara umum, kemudian difokuskan kepada topik yang lebih spesifik terkait denganmenghafal hadits dengan metode gerakan. Dalam penelitian ini digunakan 2 (dua) sumber data, yakni 1) Data primer dalam penelitian ini adalah kepala sekolah, guru, dan siswa RA Roudhotul Ishlah Margosari. 2) Data sekunder dalam penelitian ini adalah karyawan dan dokumen.

Dalam penelitian ini peneliti menggunakan metode observasi, wawancara (interview) dan dokumentasi. Analisis data di lakukan dengan mengorganisasikan data, menjabarkan ke dalam unit-unit, melakukan sintesis, menyusun ke dalam pola, memilih mana yang penting dan yang akan dipelajari, dan membuat kesimpulan yang dapat di ceritakankepada orang lain. Dalam menganalisis data penulis akan menggunakan analisa induktif yaitu cara penganalisis data yang bertitik tolak dari hal-hal yang khusus kemudian disimpulkan secara umum. Adapun teknik pengecekan keabsahan yang digunakan dalam penelitian ini yaitu: Trianggulasi 


\section{PEMBAHASAN}

1. Manajemen Pendidikan Menghafal Hadits Di RA Roudhotul Ishlah Margosari

Didalam lembaga pendidikan yang baik diperlukan manajemen pendidikan yang baik pula. Pengelolaan manajemen pendidikan haruslah memenuhi unsur-unsur manajemennya. Unsur-unsur manajemen pendidikan di RA Roudhotul Ishlah Margosari menurut bapak Ahmad Sobihan, S.P.d (wawancara tanggal 12 april 2018), selaku kepala sekolah RA Roudhotul Ishlah Margosari adalah:

1) Manajemen kurikulum

2) Manajemen peserta didik

3) Manajemen personalia sekolah (kepegawaian)

4) Manajemen ketatalaksanaan sekolah (ketatausahaan)

5) Manajemen sarana prasarana pendidikan

6) Manajemen hubungan masyarakat

7) Manajemen layanan khusus sekolah Tentunya banyak sekali lembaga pendidikan yang sudah mengadakan manajemen pendidikan di sekolah masimgmasing, namun di dalam penerapannya terkadang malah terbengkalai. Padahal tolak ukur dari keberhasilan suatu lembaga salah satunya dilihat dari manajemennya.Begitu juga di RA Roudhotul Ishlah Margosari. Awal berdiri sampai sekarang terus melakukan penambahan, pembenahan dan perbaikan terutama pada hal kemanajemenannya seperti yang dikemukakan oleh bapak Ahmad Sobihan, S.Pd (wawancara tanggal 12 april 2018), ketika ditemui di ruang kepala sekolahnya.

Dari beberapa unsur manajemen pendidikan ada sebagian yang dapat mendukung penerapan pembelajaran menghafal hadits di RA Roudhotul Ishlah Margosari. Beberapa unsur tersebut adalah manajemen kurikulum, manajemen kepegawaian, manajemen sarana prasarana dan manajemen keuangan, sebagaimana dijelaskan oleh bapak Ahmad Sobihan, S.Pd dalam waktu yang sama.

Selain unsur-unsur tersebut, terdapat pula fungsi manajemen yang dilaksanakan di RA Roudhotul Ishlah Margosari, Pernyataan ini diperkuat oleh pernyataan ibu Asroriyah, S.Kom (wawancara tanggal 12 april 2018), yang menyatakan tentang:

"ya, ada perencanaannya. Yang pertama, perencanaan dimulai dari menyusun kurikulum diantaranya menentukan materi, alat/ media belajar, sumber belajar dan penilaiannya yang semua itu tercantum dalam RPPH yang dibuat oleh guru disetiap harinya.Dari penilaian harian ke penilaian mingguan kemudian ke penilaian bulanan dan seterusnya ke penilaian semester yang tercantum di buku raport siswa. Yang kedua, pengorganisasian dilaksanakan untuk mengatur pembagian tugas guru yang menjadi guru utama/ wali kelas dan guru pendamping. Yang ketiga, pengarahan dilakukan oleh guru yang telah memiliki kompetensi tentang menghafal hadits dengan metode gerakan. Dan yang terakhir, pengontrolan yang diawasi langsung oleh kepala sekolah yang bertujuan mengukur sampai dimana tingkat kompetensi guru dalam menyampaikan materi.Pengontrolan juga diamati dari hasil penilaian disetiap akhir semesternya dengan memperhatikan tuntas/tidaknya pembelajaran tersebut sesuai dengan tujuan pembelajaran."

Berdasarkan hasil observasi dan wawancara yang mendalam dengan para nara sumber yang dilengkapi dengan dokumentasi, dapat dipaparkan hasil penelitian yang berkaitan dengan manajemen pendidikan menghafal hafits dengan metode gerakan di RA Roudhotul Ishlah Margosari yang meliputi: perencanaan, pengorganisasian, pelaksanaan, pengontrolan/ pengawasan dan penilaian.

a. Perencanaan

Dalam kegiatan manajemen pendidikan melakukan perencanaan dapat memperlancar suatu manajemen pendidikan yang efektif dan efisien, dan dengan perencanaan dapat mencapai tujuan yang ingin dicapai. Kurikulum adalah rencana tertulis tentang kemampuan yang harus dimiliki berdasarkan standar yang perlu dipelajari dan pengalaman untuk mencapai kemampuan tersebut, dan evaluasi yang perlu dilakukan untuk menentukan tingkat pencapaian kemampuan peserta didik, serta seperangkat peraturan yang berkenaan dengan pengalaman belajar peserta didik dalam mengembangkan potensi dirinya pada satuan pendidikan tertentu.

Berdasarkan kurikulum sekolah inilah setiap guru menyusun program pengajaran (program tahunan/ semester) dan program/acara pembelajaran sebagai persiapan mengajar.

Berdasarkan wawancara dengan ibu Hamidah, S.Pd.I (wawancara tanggal 13 april 2018), yang menjelaskan bahwa:

"Manajemen kurikulum disini mengatur tentang kurikulum yang diterapkan dengan segala proses yang harus dilalui, seperti pada tahap perencanaan yaitu 
menentukan desain kurikulum yang dimulai dari penyususnan kalender pendidikan, penyusunan rencana dan program pembelajaran (RPPH, RPPM, PROSEM dan PROTA), penentuan strategi dan metode pembelajaran dan pengaturan lingkungan pembelajaran."

Terdapat beberapa item perencanaan pembelajaran menghafal Hadis yaitu menyusun kalender pendidikan dan rincian pekan efektif (RPE), menyusun program tahunan (PROTA), program semester (PROSEM), program mingguan (RKM), dan menyusun rencana pelaksanaan pembelajaran harian (RPPH). Penyusunannya disesuaikan dengan tema yang sedang diterapkan. Dalam kesempatan ini pula ibu Hamidah, S.Pd.I juga mengemukakan bahwa:

"Kurikulum yang diterapkan disini adalah Kurikulum Tingkat Satuan Pendidikan atau biasa disebut dengan KTSP. KTSP memiliki 5 aspek perkembangan yang harus dipenuhi, yaitu: aspek perkembangan akhlakul karimah dan sosial emosional, pendidikan agama islam, bahasa, kognitif dan motorik yang meliputi motorik kasar dan halus."

Berdasarkan dari wawancara diatas kurikulum yang dipakai di RA Roudhotul Ishlah Margosari adalah kurikulum KTSP yang memiliki 5 aspek perkembangan yang diterapkan dalam pembelajaran menghafal hadits di RA Roudhotul Ishlah Margosari.

Selain dari manajemen kurikulum, unsur manajemen pendidikan yang mendukung penerapan pembelajaran menghafal hadits adalah manajemen sarana dan prasarana. Perencanaan dalam manajemen sarana prasarana meliputi beberapa tahapan, seperti yang dikemukakan oleh ibu Nur Afidah (wawancara tanggal 13 april 2018), yang mengatakan:

"Tahapan yang ada di dalamnya adalah mengatur tentang pengadaan, pemakaian, pengurusan kebutuhan seperti pengadaan fasilitas, alat, media dan sumber belajar seperti buku pedoman guru. Dimana buku pedoman guru tersebut sangatlah penting untuk bahan rujukan yang jelas bagi guru agar tidak terdapat kekeliruan dalam penyampaian materi kepada siswa. Karena jika terdapat kekeliruan yang fatal dapat mempengaruhi proses belajar siswa dikemudian hari atau di tingkat pendidikan selanjutnya. Di dalam manajemen sarana prasarana juga terdapat tahap pencatatan yang berguna untuk mengetahui berapa banyak sarana prasarana yang dimiliki. Dan yang terakhir adalah tahap pertanggung jawaban, lebih jelasnya proses perawatan agar sarana prasarana tetap terjaga kebersihan dan kerapiannya."

Terlaksananya perencanaan dalam manajemen sarana prasarana terlihat dari ketersediaannya buku-buku pedoman guru sebagai sumber belajar dan rujukan guru yang menunjang penerapan pembelajaran menghafal hadits di RA Roudhotul Ishlah Margosari.Selain dari itu tampak kebersihan dan kerapian buku-buku pedoman guru maupau buku-buku cerita yang disediakan untuk anak yang merupakan perpustakaan mini agar menumbuhkan kecintaan membaca pada anak.

Perencanaan lain juga memerlukan perhatian yang serius, yaitu perencanaan di manajemen keuangan. Manajemen keuangan merupakan hal yang penting untuk berjalannya suatu proses tanpa kecuali didalam penerapan pembelajaran menghafal hadits di RA Roudhotul Ishlah Margosari. Mengutip pernyataan ibu Jematun, S.Pd.I (wawancara tanggal 13 april 2018), tentang manajemen keuangan di RA Roudhotul Ishlah Margosari yaitu:

"Manajemen keuangan disini adalah proses yang dimulai dari perencanaan, pembukuan, pembelanjaan, pengawasan dan pertanggungjawaban keuangan sekolah yang dibebankan kepada seorang bendahara sekolah."

Dalam kesempatan yang sama ditanya tentang hubungan antara manajemen keuangan dengan penerapan menghafal hadits, beliau menjawab:

"Tentu saja ada!, karena segala sesuatu kegiatan tak luput dari keuangan. Sama halnya dengan penerapan menghafal hadits yang memerlukan alokasi dana terutama untuk penyediaan sumber, alat dan media belajar juga untuk kegiatan peningkatan kompetensi guru."

Didalam perencanaannya memerlukan alokasi dana yang ditujukan untuk menyediakan sumber, alat dan media belajar. Alokasi dana itu juga diperuntukkan kegiatan peningkatan kompetensi guru seperti bimtek, diklat, workshop ataupun seminar.

Berdasarkan beberapa wawancara yang peneliti lakukan dapat ditarik kesimpulan bahwa manajemen pendidikan menghafal hadits di RA Roudhotul Ishlah Margosari didukung oleh perencanaan yang matang di berbagai manajemen pendukung yaitu manajemen kurikulum, manajemen sarana 
dan prasarana, manajemen kepegawaian dan manajemen keuangan.

b. Pengorganisasian

Pengorganisasian dalam kegiatan pembelajaran yang dimaksudkan untuk menentukan pelaksana tugas dengan jelas kepada setiap personil sekolah sesuai bidang, wewenang, mata pelajaran, dan tanggung jawabnya. Sebagaimana yang dikatakan oleh kepala RA Roudhotul Ishlah Margosari bahwa menyusun dan menentukan pendidik yang mengajar melibatkan seluruh staf pengajar dan tenaga pendidikan sesuai dengan bidang studi masing-masing.

Penerapan fungsi pengorganisasian yakni kepala sekolah sebagai pemimpin bertugas untuk menjadikan kegiatankegiatan sekolah yang menjadi tujuan sekolah dapat berjalan dengan lancar. Kepala sekolah perlu mengadakan pembagian kerja yang jelas bagi guru-guru yang menjadi anak buahnya. Dengan pembagian kerja yang baik, pelimpahan wewenang dan tanggung jawab yang tepat, serta mengingat prinsip-prinsip pengorganisasian, kiranya kegiatan sekolah akan berjalan dengan lancar dan tujuan dapat tercapai.

Berdasarkan wawancara dengan kepala sekolah (wawancara tanggal 12 april 2018), yang mengatakan bahwa:

"Pembagian kerja yang jelas kepada guru-guru sesuai dengan prinsip penempatan sesuai dengan keahliannya dan menjalin hubungan perilaku yang efektif antar pendidik dan tenaga kependidikan, sehingga mereka dapat bekerja sama secara efisien guna mencapai tujuan dan sasaran tertentu. Sedangkan surat pembagian tugas mengajar disesuaikan dengan kompetensi masing-masing guru yang telah memenuhi standarisasi seorang pendidik."

Pembagian kerja dan tugas mengajar tercantum dalam surat keputusan yang dibuat oleh kepala sekolah. Sedangkan surat keputusan pengangkatan guru dan kepala sekolah direkomendasikan dan ditanda tangani oleh yayasan. Pengangkatan guru dan kepala sekolah disesuaikan dengan tingkat kemampuan dan standarisasi pendidik dan tenaga pendidik.

Dari hasil dokumentasi madrasah menyatakan bahwa belum semua guru memiliki standar kompetensi.Khususnya pada penerapan pembelajaran menghafal hadits belum semua guru memiliki kompetensinya. Hal ini senada dengan pernyataan ibu Asroriyah, S.Kom (wawancara tanggal 13 april 2018), yang mengatakan bahwa Belum semua guru memiliki kompetensi guru, untuk sementara ini yang sudah ada 3 guru yang memiliki kompetensi guru untuk penerapan metode menghafal hadits.

Kompetensi guru sangatlah penting untuk memenuhi standarisasi pendidik dan tenaga kependidikan yang dapat menjadi tolak ukur dari keberhasilan pendidikan di suatu lembaga pendidikan. Kegiatankegiatan tersebut meliputi bimtek, diklat, workshop atau seminar yang diselenggarakan beberapa pihak baik dari dinas pendidikan, departemen agama, sponsor-sponsor dan banyak lagi penyelenggara yang bersangkutan dengan pendidikan anak usia dini. Dalam hal ini perlu kontribusi besar dari sekolah dalam rangka mengikutsertakan guru dalam kegiatan-kegiatan peningkatan kompetensi guru. Ditanya tentang masalah tersebut, ibu Asroriyah, S.Kom menjawab:

"Pasti. Ketika ada bimtek, diklat, workshop ataupun seminar yang dapat meningkatkan kemampuan/ kompetensi guru dari sekolah pasti mengirim/ mengutus guru untuk ikutserta. Dengan diikutsertakannya guru dalam kegiatan-kegiatan tersebut bisa menambah wawasan, ilmu pengetahuan dan tentunya pengalaman yang dapat ditularkan ke dewan guru lain dan diterapkan di sekolah sesuai bidangnya."

Berdasarkan hasil wawancara dan dokumentasi yang telah dilakukan dapat ditarik kesimpulan bahwa pengorganisasian di RA Roudhotul Ishlah Margosari meliputi pembagian kerja yang di dasarkan pada prinsip penempatan sesuai dengan keahliannya dan menjalin hubungan perilaku yang efektif antar pendidik dan tenaga kependidikan, sehingga dapat bekerja sama secara efisien guna mencapai tujuan dan sasaran tertentu. Sedangkan surat pembagian tugas mengajar disesuaikan dengan kompetensi masing-masing guru yang telah memenuhi standarisasi seorang pendidik. Sedangkan kontribusi penuh dalam kegiatan-kegiatan peningkatan kompetensi guru dan pendanaannya di alokasikan oleh sekolah.

c. Pelaksanaan

Proses pelaksanaan manajemen pendidikan di RA Roudhotul Ishlah Margosari terdapat pada proses penerapan pembelajaran menghafal hadits dengan metode gerakan. Di dalam proses ini 
terdapat beberapa bagian diantaranya: 1). Strategi Pembelajaran 2). Metode pembelajaran 3). Kepemimpinan dalam pembelajaran. 4). Pelaksanaan kegiatan belajar mengajar.

1) Strategi Pembelajaran

Setiap guru dalam melaksanakan proses pembelajaran mempunyai cara atau strategi dan metode sendiri, ini dikarenakan strategi dan metode pembelajaran selalu menyesuaikan dengan materi pembelajaran yang sedang berlangsung. Dalam perspektif ini tidak ada metode yang paling baik dalam proses pembelajaran. Yang ada adalah guru yang kreatif dan inovatif dalam pembelajaran sehingga dia dapat menggunakan berbagai macam metode, dan tidak tergantung hanya kepada satu metode pembelajaran.

Dari hasil data yang didapat penulis dalam pengamatan langsung saat proses pembelajaran dikelas terlihat bahwa strategi yang diterapkan cenderung sentralisitis (teachers centered), artinya guru dalam proses pembelajaran terpola dan terkondisikan dengan situasi aktif, namun siswa pada posisi yang pasif. Dengan situasi seperti ini maka komunikasi dalam proses pembelajaran hanya terjadi satu arah antara guru kepada siswa tanpa ada respon aktif dari siswa, kecuali apabila guru memberikan pertanyaan kepada siswa diantara penyampaian materi saja.

Dengan strategi pembelajaran seperti ini sesungguhnya tidak memberikan ruang gerak kepada siswa untuk berperan secara aktif dalam proses pembelajaran. Harus disadari bahwa paradigma belajar dan pembelajaran modern sekarang sudah berubah dari yang bersifat teacher centered, menjadi berpusat pada siswa (student centered), dari cara belajar guru aktif menjadi cara belajar siswa aktif dan lain sebagainya.

Kenapa hal tersebut bisa terjadi, sesuai dengan hasil pengamatan penulis dapat disimpulkan, hal seperti ini terjadi memang ada kecenderungan guru hanya menguasai konsep strategi umum yang selama ini dipakai oleh para guru, seharusnya strategi pembelajaran yang lain diterapkan dalam proses pembelajaran, sehingga siswa menjadi aktif dan menjadi bagian penting dalam pembelajaran.

2) Metode Pembelajaran

Menurut teori sumber daya manusia, suasana pembelajaran yang baik adalah mengikuti konsep pembelajaran yang selalu berpusat kepada siswa, karenanya kepentingan memilih metode pembelajaran yang tepat akan memberikan kemerdekaan bagi siswa dalam menciptakan kreatifitasnya dan berkarya sesuai prinsip-prinsip pembelajaran. Metode pembelajaran sangat terkait dengan berbagai komponen pembelajaran yang akan diajarkan pada siswa. Komponen ini sangat menentukan kualitas dan hasil dari proses pembelajaran.

Untuk memperoleh informasi yang berhubungan dengan metode pembelajaran menghafal Hadis, penulis melakukan wawancara dan pengamatan. Wawancara itu dilakukan di dua tempat, yakni di ruang kelas dan di kantor (ruang guru). Mengenai hal tersebut peneliti bertanaya: Metode apakah yang digunakan guru dalam proses pembelajaran menghafal hadits? dalam hal ini ibu Hamidah (wawancara tanggal 13 april 2018), menjawab:

"Pada awalnya guru menggunakan metode ceramah yang mengharuskan siswa mendengarkan, melafalkan dan menghafalkan tanpa ada pertimbangan bagaimana agar anak tertarik dalam pembelajaran tersebut. Anak cenderung bosan karena anak pada jenjang pendidikan anak usia dini, anak cenderung aktif dan tidak mau diam."

Selanjutnya dari jawaban di atas menggambarkan bahwa metode yang diguanakan adalah metode ceramah yang mengharuskan siswa mendengarkan, melafalkan dan menghafalkan tanpa ada pertimbangan bagaimana agar anak tertarik dalam pembelajaran tersebut. Namun pada kenyataannya anak cenderung bosan karena anak selalu aktif dan tidak mau diam.

Dari hasil wawancara tersebut diketahui bahwa guru sebenarnya bukan tidak tahu atau tidak mengerti beberapa metode-metode itu, nama-nama metode itu sudah diketahuinya, tetapi tidak pernah diterapkannya. Karena keterbasan pengetahuan dan pengalaman yang belum memenuhi standar kompetensi guru.

Selanjutnya peneliti bertanya tentang metode apakah yang diterapkan dalam menghafal hadits? dan kapan mulai diterapkan? Kembali ibu Hamidah S.Pd.I (wawancara tanggal 13 april 2018), menjawab:

"Metode yang digunakan adalah metode gerakan dalam menghafal hadits. penerapannya baru dimulai 
setelah kami mengikuti "Bimtek Menghafal Hadits Dengan Metode Gerakan" yang diselenggarakan di Islamic Centre Bandar Lampung 3 tahun silam tepatnya pada tahun 2015."

Metode gerakan adalah salah satu metode yang dapat diterapkan dalam menghafal hadits. Menghafal hadits dengan metode gerakan adalah usaha untuk mengingat sabda, perbuatan, ketetapan Nabi Muhammad SAW dengan menggunakan cara perbuatan yang bergerak atau melalui gerakan. Dijelaskan kembali tujuan dari pembelajaran menghafal hadits adalah:

"Menghafal hadits adalah salah satu indikator dalam aspek perkembangan pendidikan agama islam yang bertujuan untuk memotivasi anak agar senantiasa dalam kebaikan, ketauladanan karena hadits memberikan contoh dari Nabi Muhammad sebagai uswatun hasanah dan pembiasaan tingkah laku sehingga dapat diamalkan dalam kehidupan sehari-hari."

Dengan menghafal hadits dapat memotivasi anak agar senantiasa dalam kebaikan, meneladani Nabi Muhammad SAW dan mengamalkan dikegiatan seharihari dengan harapan mencetak generasi masa depan yang berjiwa religius.

3) Kepemimpinan dalam pembelajaran.

Didalam pembelajaran guru adalah pemimpin pendidikan yang mempengaruhi para murid untuk melakukan kegiatan belajar dalam rangka mencapai tujuan pembelajaran. Kepemimpinan dalam organisasi sekolah adalah kepemimpinan pendidikan, sedangkan kepemimpinan pendidikan merupakan proses aktivitas peningkatan pemanfaatan sumber daya manusia di sekolah secara lebih kreatif dan manajemen pendidikan membuat keputusan untuk kelangsungan pembelajaran secara efektif.

Berdasarkan hasil pengamatan langsung peneliti di kelas menunjukkan bahwa guru adalah orang yang bertanggung jawab penuh terhadap proses belajar mengajar (PBM). Jadi yang menjalankan kepemimpinan dalam proses pembelajaran adalah guru, karena dalam pembelajaran guru berupaya selalu mempengaruhi murid agar mau belajar dengan senang. Semakin senang perasaan siswa dalam mengikuti pelajaran, diharapkan tujuan pembelajaran dapat tercapai dengan optimal.

Berkenaan dengan kepemimpinan guru dan dari pengamatan penulis, bahwa dalam proses kepemimpinan pembelajaran guru sudah melakukan 2 (dua) hal penting, yaitu:

a) Sebelum masuk kelas

1) Merumuskan tujuan pembelajaran yang tertuang dalam RPP yang mencakup aspek sosial emosional, pendidikan agam islam, bahasa, kognitif dan motorik.

2) Memberi pertimbangan materi yang akan diajarkan dengan mempersiapkan sumber belajar, alat peraga dan alat penilaian.

3) Merancang alokasi waktu sesuai dengan materi pembelajaran yang akan disampaikan.

b) Pada waktu guru di dalam kelas

1) Sebelum pelajaran dimulai, guru melakukan kegiatan pembuka dengan bernyanyi dan bercerita.

2) Melakukan apersepsi.

2) Memperhatikan keragaman anak.

3) Memperlakukan anak dengan cara yang berbeda sesuai karakter masing-masing.

4) Mempersiapkan program perbaikan pembelajaran.

5) Mengadakan pengukuran terhadap berbagai pencapaian siswa.

4). Pelaksanaan kegiatan belajar mengajar.

Kegiatan belajar mengajar dibanyak lembaga pendidikan dilaksanakan didalam kelas, namun ada beberapa materi pembelajaran yang dapat dilaksanakan diluar kelas. Ada juga pembelajaran yang fleksibel yaitu dapat dilaksanakan didalam dan diluar kelas. Seperti dalam pembelajaran menghafal hadits ini dapat dilaksanakan di dalam dan di luar kelas. Pernyataan ini diperkuat oleh penjelasan dari ibu Hamidah, S.Pd.I :

"Kalau penerapannya bisa dilaksanakan di dalam dan di luar kelas.

Langkah pertama, kenalkan siapa Rasulullah SAW, sampai anak memahami bahwa anak Rasulullah SAW adalah seorang manusia yang sempurna akhlaknya, baik budi pekerti dan tutur katanya.Dia adalah utusan Alloh SWT yang mencintai umatnya hingga akhir hidupnya.Pemimpin sejati yang pantas untuk diidolakan. Langkah kedua, pilih hadits yang mau diajarkan, bisa disesuaikan dengan tema yang ada di sekolah 
masing-masing. Langkah ketiga, ceritakan kisah penuh hikmah tentang akhlak Rasulullah SAW yang berkenaan dengan hadits yang akan diajarkan. Bisa dari asbabul wurudnya bila ada, atau cerita lainnya yang dapat menggambarkan dengan jelas akhlak mulia baginda Nabi yang akan kita ajarkan pada anak. Langkah keempat, bacakan hadits yang diajarkan dengansebelumnya mulailah dengan kalimat "qaala Rasulullahi salallahu 'alaihi wasallam" atau "Rasulullah sallahu 'alaihi wasallam bersabda". Setelah itu, baru mulai membaca hadits dengan jelas dan benar beserta artinya. Langkah kelima, contohkan gerakan hadits dengan benar agar dengan mudah anak-anak dapat meniru gerakan tersebut.

Pelaksanaan pembelajaran menghafal hadits ini dapat disesuaikan dengan tema materi pembelajaran dan dengan kreatifitas guru dalam menyampaikannya. Pembelajarannya dibuat semenarik mungkin agar anak lebih mudah memahami dan menghafalkan haditsnya.

Berdasarkan dari pengamatan dan wawancara diatas peneliti menarik kesimpulan bahwa pelaksanaan pembelajaran menghafal hadits di RA Roudhotul Ishlah Margosari telah mengalami perubahan yang semula menggunakan metode ceramah kemudian berganti menggunakan metode gerakan yang bertujuan mempermudah anak menghafal hadits.

d. Pengontrolan/ Pengawasan

Pengawasan diperlukan untuk melihat sejauh mana hasil tercapai. Pelaksanaan manajemen pendidikan menghafal hadits tidak terlepas dari pengawasan. Dalam hal ini yang terlibat dalam pengawasan yaitu kepala sekolah dan guru kelas. Namun struktur organisasi sudah dapat memberikan tanggung jawab individu, karena tidak semua bisa dilihat oleh kepala sekolah langsung, akan tetapi pengawasan akan dilakukan manajer setiap unit-unitnya dan pelaporannya kepada kepala sekolah.

Kegiatan yang berlangsung di awasi secara langsung terutama guru kelas dan guru pendamping kelas masing-masing seperti yang dikemukan oleh kepala sekolah bapak Ahmad Sobihan, S.Pd yang menyatakan bahwa: yang terlibat dalam pengawasan yaitu kepala sekolah dan guru kelas. pengawasan di awasi secara langsung terutama guru kelas dan guru pendamping kelas masing-masing. Dan untuk pelaporannya kepada kepala sekolah yang disetorkan oleh manager setiap unitnya.

Dari hasil wawancara dan observasi yang telah dilakukan dapat diambil kesimpulan bahwa pengawasan manajemen pendidikan menghafal hadits di RA Roudhotul Ishlah Margosari dilakukan oleh guru kelas dan pendamping kelas kemudian pelaporannya diberikan kepada kepala sekolah.

e. Penilaian

Evaluasi atau Penilaian pada dasarnya bertujuan untuk mengetahui perkembangan hasil belajar siswa dan hasil mengajar guru. Informasi hasil belajar atau hasil mengajar berupa kompetensi dasar yang dikuasai dan yang belum dikuasai oleh siswa. Hasil belajar siswa digunakan untuk memotivasi siswa, dan untuk perbaikan serta peningkatan kualitas pembelajaran oleh guru.Berdasarkan informasi yang terkumpul yang diperkuat dengan dokumentasi bahwa penilaian terhadap pembelajaran menghafal Hadis ditekankan pada penguasaan materi pelajaran yang meliputi hafalan, kefasihan, dan pembiasaannya.

Kegiatan evaluasi pemebelajaran secara umum bertujuan untuk mengetahui tingkat pencapaian tujuan dari suatu program, juga melalui evaluasi berhasil tidaknya kegiatan pembelajaran dapat diketahui. Dari hasil evaluasi dapat memberikan masukan kepada guru dan pengambil kebijakan lainya tentang kemungkinan perlunya peninjauan kembali terhadap rumusan kompetensi atau tujuan, materi atau metode pembelajaran yang ditempuh.

Berdasarkan observasi dan Dokumen Buku Pedoman Penilaian RA Roudhotul Ishlah Margosari yang telah dilakukan penilaian pembelajaran menghafal hadis diklasifikasikan ke dalam empat kategori, yaitu:

a. BSB (berkembang sangat baik), didefinisikan penguasaan materi juga menghafal hadits secara tuntas dan tartil (fasih dan sesuai hukum tajwidnya).

b. BSH (berkembang sesuai harapan), menunjuk kemampuan penguasaan materi dan hafalannya tuntas tapi belum mencapai predikat tartil dan tidak dibantu oleh guru.

c. MB (mulai berkembang), menunjuk kepada kemampuan menghafal hadis kurang lancar dan masih dibantu oleh guru.

d. BB (belum berkembang), menunjuk kepada kemampuan menghafal hadis 
tidak lancar, masih tersendat-sendat dan masih banyak dibantu guru.

Evaluasi pada manajemen pendidikan menghafal hadis di RA Roudhotul Ishlah Margosari ditandai dengan pelaksanaan evaluasi disemua manajemen pendukung terutama pada manajemen kurikulum.

2. Faktor Pendukung Dan Penghambat Manajemen Pendidikan Menghafal Hadits Dengan Metode Gerakan Di RA Roudhotul Ishlah Margosari

a. Faktor Pendukung

Dalam dunia ilmu pengetahuan dan teknologi yang semakin maju dan canggih sekarang ini, maka segala potensi sumber daya alam (SDA), Sumber Daya Manusia (SDM), serta potensi-potensi yang lain harus dimanfaatkan dan jadikan modal berharga dalam meningkatkan proses pendidikan. Berkaitan dengan hal tersebut, maka faktor pendukung adalah segala potensi yang dimiliki sekolah yang dapat berfungsi sebagai alat bantu dalam rangka mencapai tujuan pendidikan secara maksimal. Dalam perspektif ini guru memegang peranan yang sangat signifikan dalam proses pendidikan. Keberhasilan satu proses pendidikan sangat tergantung kepada bagaimana guru memerankan dirinya. Namun demikian diluar hal tersebut faktor yang juga mendukung adalah adanya pengelolaan manajemen pendidikan yang baik.

Sebagaimana wawancara yang dilakukan dengan ibu Hamidah, S.Pd.I (wawancara tanggal 13 april 2018), tentang faktor pendukung manajemen pendidikan menghafal hadits salah satunya adalah ketersediaan buku pedoman guru yang merupakan salah satu bagian dari tahapan pelaksanaan manajemen sarana prasarana.

Untuk memperjelas pemahaman tersebut berikut ini penulis paparkan faktor-faktor pendukungnya sebagai berikut :

1) Gur u

Berkaitan dengan hal ini guru dimaksud bukan hanya dipandang dari segi kuantitasnya saja, akan tetapi lebih dari itu yang diharapkan adalah kualitas dari seorang guru. Guru sebagai salah satu bagian integral dalam lembaga pendidikan wajib memenuhi dan mempunyai syarat dan kecapakan serta kompetensi akademik sesuai dengan mata pelajaran yang embannya. Dengan kompetensi akademik yang dimilikinya diharapkan mampu mengemban amanah dalam kerangka proses pembelajaran yang lebih baik untuk mencapai tujuan bersama. Didalam pelaksanaan manajemen pendidikan diperlukan juga guru yang berkompetensi di bidang kemanajemenan, namun dalam hal ini peneliti menemukan belum adanya tenaga yang berkompetensi di bidang tersebut di RA Roudhotul Ishlah Margosari ini.

2) Kurikulum

Kurikulum termasuk salah satu faktor pendukung yang sangat penting dalam sistem pendidikan nasional. Dalam konteks ini kurikulum juga dipandang sebagai sebuah haluan untuk menentukan kemana arah pendidikan itu akan dibawa, melalui proses pembelajaran dikelas. Hal tersebut dapat dipahami mengingat dengan kurikulum tersebut maka dalam proses pembelajaran yang dilaksanakan menemukan bentuk, arah dan tujuan. Untuk RA Roudhotul Ishlah Margosari menggunakan kurikulum tingkat satuan pendidikan (KTSP) digunakan pada Tahun Pelajaran 2010/2011, Tidak lama Kurikulum 2013 diterapkan oleh pemerintah pada Tahun Pelajaran 2014/2015. Namun di awal tahun 2015 terjadi perubahan kurikulum lagi karena kebijakan pemerintah pusat yang mengembalikan kembali ke KTSP untuk dipakai oleh sekolahsekolah yang belum terlalu siap untuk memakai kurikulum 2013.

Dalam KTSP, pemerintah menetapkan struktur kurikulum, selanjutnya Badan Standar Nasional Pendidikan (BSNP) menetapkan Standar Kompetensi (SK) dan Kompetensi Dasar (KD). Berdasarkan Standar Kompetensi dan Kompetensi Dasar, pihak sekolah mengembangkan KTSP. Pemberlakuan KTSP memberikan peluang guru untuk lebih kreatif, hambatannya terletak pada kemampuan guru dalam menyusun Rencana Pelaksanaan Pembelajaran Harian (RPPH) dan Sistem Penilaian (SP) yang menjadi syarat mutlak untuk penyusunan KTSP.Bagi guru pengembangan KTSP merupakan hal dan pengalaman baru. 
Pengembangan kurikulum adalah bagian utama dari manajemen kurikulum yang memuat pembelajaran menghafal hadis. Pelaksanaan manajemen kurikulum terlihat dari pelaksanaan pembelajaran tersebut. Dari pengamatan yang dilakukan oleh peneliti menunjukkan bahwa manajemen kurikulum di RA Roudhotul Ishlah Margosari sudah cukup baik ditandai dengan adanya penerapan kurikulum yang teratur dimulai dari pembuatan PROTA, PROSEM, RPPM, dan RPPH yang buat oleh masing-masing guru kelas.

3) Sarana dan Prasarana

Sebagaimana kita ketahui bersama, sarana dan prasarana yang memadai sangat mutlak dibutuhkan agar proses pembelajaran dikelas berjalan dengan baik dan lancar. Merujuk pada peraturan Mendiknas no. 24 tahun 2007, bahwa yang dimaksud "sarana" adalah perlengkapan pembelajaran yang dapat dipindah-pindahkan, sedangkan "prasarana" adalah fasilitas dasar untuk menjalankan fungsi sekolah/madrasah. Dalam konsepsi yang lain dijelaskan bahwa sarana diterjemahkan sebagai perabot, peralatan atau bahan yang secara langsung digunakan dalam proses pembelajaran disekolah/madrasah, sedangkan prasarana pendidikan dimaknai sebagai perangkat dasar yang secara tidak langsung menunjang pelaksanaan proses pembelajaran disekolah/madrasah.

Sehubungan dengan konsepsi diatas, kaitannya dengan manajemen pendidikan menghafal hadits di RA Roudhotul Ishlah Margosari yang mencakup manajemen sarana dan prasarana yang dimiliki dapat dikatakan cukup baik ditandai dengan adanya sarana prasarana yang memadai, namun demikian apabila dibandingkan dengan fasilitas sarana dan prasarana sekolah lain, tentu sangat jauh berbeda. Hal ini mungkin bisa jadi dikarenakan adanya perhatian pemerintah terhadap keberadaan sekolah yang bernuansa islami yang masih dianggap sebelah mata, bahkan ada kecenderungan dianggap sebagai anak "tiri".Sarana dan prasarana sebagai perangkat dasar dalam melaksanakan fungsi sekolah/madrasah harus mendapat perhatian serius, karena dengan adanya sarana dan prasarana yang memadai maka memungkinkan tujuan sekolah dan tujuan pembelajaran dapat tercapai dengan baik.

Berkaitan dengan sarana dan prasarana diatas termasuk didalamnya adalah hal yang berkaitan dengan media atau alat pembelajaran. Dari hasil pengamatan penulis, bahan dan alat yang digunakan guru dalam proses pembelajaran menghafal hadis cenderung klasik, misalnya ; buku pedoman yang dijadikan sumber pelajaran hanya buku yang dikeluarkan oleh salah satu penerbit, sedangkan kitab Hadis lainnya sebagai sumber pelajaran penunjang sudah dimiliki oleh madrasah, tetapi pemanfaatannya sangat minim. Disamping itu juga guru belum mempunyai ide-ide yang beragam yang dapat menunjang proses belajar mengajar dan membuat pembelajaran semakin menarik.

Berdasarkan observasi di lapangan dan wawancara dengan ibu Nur Afidah (wawancara tanggal 13 april 2018) menyebutkan bahwa adapun media yang digunakan adalah spidol dan white board serta buku pedoman. Sarana yang berupa Laptop, dan LCD belum tersedia khususnya untuk proses pembelajaran, hal ini disebabkan oleh keterbatasan alokasi dana yang tersedia.

Berdasarkan wawancara diatas dapat diambil kesimpulan bahwa manajemen sarana prasarana di RA Roudhotul Ishlah Margosari masih belum maksimal, karena ketersediaan alat dan sumber pembelajaran yang minim dan masih perlu alokasi dana yang mencukupi untuk memenuhi sarana prasarana yang lebih lengkap.

4) Kepemimpinan Kepala Sekolah

Dari pengamatan penulis diperoleh fakta bahwa kepemimpinan kepala madrasah cukup baik, dan manajemen yang diterapkan di sekolah juga sudah cukup memadai. Berkaitan dengan hal ini dapat dilihat dengan adanya sistem pendelegasian setiap ada tugas ataupun permasalahan yang menyangkut masalah pembelajaran. Hal ini dapat dibuktikan dengan adanya kebijakan kepala sekolah dalam mengontrol serta memaksimalkan komponen sekolah 
yang harus dipenuhi agar pembelajaran manajemen berjalan dengan baik, yaitu dengan adanya staf administrasi yang bekerja sesuai dengan job description yang telah diamanahkan kepadanya. Hal ini dapat kita lihat faktanya antara lain :

(a) Kepala sekolah belum dapat dijadikan sebagai pembimbing utama bagi guru dalam menyusun Rencana Pelaksanaan Pembelajaran Harian (RPPH) sebagaimana pelaksanaan KTSP, maupun sebagai supervisor bagi pelaksanaan kegiatan belajar mengajar (KBM), karena adanya keengganan sebagaian guru untuk berkonsultasi dengan kepala sekolah berkaitan dengan masalah yang dihadapi.

(b) Kepala Sekolah dibebani dengan tugas tambahan lainnya seperti sebagai pembinaan siswa dan konseling.

(c) Kerapian administrasi keuangan terlihat sangat memadai, hal ini terlihat dengan adanya bendahara khusus yang mengurus keuangan sekolah yang berkaitan dengan uang yang bersumber dari APBN (dana BOS), selanjutnya ada satu orang yang juga bertugassebagai bendahara keuangan yang bertugas secara adminstrasi keuangan yang bersumber dari iuran siswa.

b. Faktor Penghambat

Faktor penghambat adalah tidak terpenuhinya beberapa unsur, atau salah satu unsur yang seharusnya ada, akan tetapi pada kenyataannya hal tersebut tidak ada. Berdasarkan wawancara penulis dengan Kepala sekolah dan guru, ditemukan masalah yang muncul dalam rangka pelaksanaan manajemen pendidikan menghafal hadis di RA Roudhotul Ishlah Margosari, yaitu adalah tidak adanya tenaga kependidikan di bidang manajemen, karakteristik siswa dan lingkungan. Selama ini pelaksanaan manajemen pendidikan menghafal hadis di RA Roudhotul Ishlah Margosari masih dipegang oleh kepala sekolah sepenuhnya, guru hanya membantu pelaksanaannya di dalam ruang lingkup pembelajaran saja.Dengan ketidaktersediaan tenaga kependidikan yang kompeten di bidang manajemen berdampak pada kurang maksimalnya manajemen pendidikan menghafal hadis di RA Roudhotul Ishlah Margosari, Hal ini dinyatakan oleh Kepala
Sekolah Ahmad Sobihan, S.Pd. (wawancara tanggal 12 april 2018)

Selain itu faktor penghambat lain adalah karakteristik siswa. Karakter siswa yang beragam menjadi hambatan karena siswa mempunyai karakter individual. Siswa ada yang mudah merespon dan ada yang sulit merespon terhadap materi yang diberikan. Keberagaman tersebut menjadi suatu tantangan bagi guru agar dapat merespon dan memperhatikan setiap karakter dari masing-masing siswa tanpa mengecualikan salah satu siswa yang mempunyai karakter yang kurang baik.

Lingkungan adalah salah satu faktor penghambat lain yang mempengaruhi penerapan menghafal hadits di kegiatan sehari-hari, terutama di lingkungan keluarga dan masyarakat. Perkembangan mental dan spiritual siswa tergantung dari pendidikannya di keluarga dan lingkungannya sehari-hari. Dampak lingkungan bagi perkembangan siswa begitu penting. Lingkungan yang baik memberikan dampak yang baik pula bagi siswa, begitu juga sebaliknya.

Didalam pendidikan di sekolah banyak memberikan ilmu oengetahuan dan pengalaman yang baik, namun terkadang antara pendidikan yang diterapakan disekolah dan dilingkungan keluarga dan masyarakat sangatlah berbeda. Terjadi ketidak sinkronan antara keduannya, sehingga tidak tercapai tujuan penerapan pembelajaran menghafal hadits dalam kehidupan seharai-hari.

3. Solusi Manajemen Pendidikan Menghafal Hadis Di RA Roudhotul Ishlah Margosari

Setelah mengetahui faktor pendukung dan penghambat di atas upaya yang dilakukan oleh sekolah dalam mengatasi masalah tersebut adalah :

a. Meningkatkan kompetensi guru melalui pendidikan, pelatihan, diklat, workshop, seminar dan Kelompok Kerja Guru (KKG).

b. Mengikutsertakan guru menempuh pendidikan kejenjang lebih tinggi.

c. Melakukan seleksi tenaga kependidikan yang berkompeten.

d. Melakukan koordinasi dengan pihak yang dapat dijadikan donator dalam pengadaan sarana prasarana.

\section{E. Kesimpulan}

Berdasarkan data, fakta dan analisis hasil pembahasan dari penelitian dapat diuraikan bahwa unsur manajemen pendidikan yang mendukung penerapan pembelajaran menghafal hadits di RA Roudhotul Ishlah Margosari adalah manajemen kurikulum, manajemen 
kepegawaian, manajemen sarana prasarana dan manajemen keuangan. Manajemen pendidikan menghafal hafits di RA Roudhotul Ishlah Margosari menggunakan metode gerakan. Menghafal hadits dengan metode gerakan adalah usaha untuk mengingat sabda, perbuatan, ketetapan Nabi Muhammad SAW dengan menggunakan cara perbuatan yang bergerak atau melalui gerakan. Faktor pendukung manajemen pendidikan menghafal hadits salah satunya adalah guru, kurikulum, sarana prasarana dan kepemimpinan kepala sekolah. Sedangkan faktor penghambatnya yaitu adalah tidak adanya tenaga kependidikan di bidang manajemen, karakteristik siswa dan lingkungan.

\section{DAFTAR PUSTAKA}

Nur Aedi, 2015. Dasar-Dasar Manajemen Pendidikan, , hal.30

Undang-Undang Republik Indonesia Nomor 20 tahun $2003 \quad$ Tentang Sistem PendidikanNasional dan UU Nomor 14 Tahun 2005 Tentang Guru dan Dosen, pasal 3

Rustam Ibrahim, Jurnal Manajemen Akhlakul Karimah Manajemen Pendidikan Islam, hal.29 | ISSN: 2356-2447-XIII

Departemen Agama RI, 1992. Alqur'an dan Terjemahnya. , Jakarta : Al-Huda

Utsman Bin Hasan Bin Ahmad As-Syakur Al Khawabiri, Durrotun Nasihihin, Jakarta : Daru Ihya' Kitabil Arabi, hal 54

Direktorat Pembinaan Pendidikan Anak Usia Dini Direktorat Jenderal Pendidikan Anak Usia Dini, Nonformal, Dan Informal Kementrian Pendidikan Nasional., 2012. Pedoman Penyelenggaraan Pendidikan Anak Usia Dini Berbasis Keluarga, 